\title{
RESIDUAL ACTIVITY OF HERBICIDES APPLIED TO COTTON ON CROPS CULTIVATED IN SUCCESSION ${ }^{1}$
}

\author{
ELIEZER ANTONIO GHENO ${ }^{2 *}$, RUBEM SILVÉRIO DE OLIVEIRA JUNIOR ${ }^{2}$, JAMIL CONSTANTIN $^{2}$, HUDSON \\ KAGUEYAMA TAKANO ${ }^{2}$, ALEXANDRE GEMELLI ${ }^{2}$
}

\begin{abstract}
Herbicides with high persistence in soil can cause problems for crops sown in succession to their application. Thus, the aim of this study was to estimate, in greenhouse conditions, the safe period of time after application of preemergent herbicides used on cotton crops (isolated or in mixtures) for the crops grown in succession (bean, corn, and soybean). The experimental design was completely randomized in a factorial scheme $(5 \times 11)+1$, with five repetitions. For each experiment, treatments combined different time periods between herbicide application and sowing of crops $(280,210,140,70$, and 0 days before sowing of crops) with eleven herbicide treatments: fomesafen $\left(625 \mathrm{~g} \mathrm{ha}^{-1}\right)$ prometryne $\left(1250 \mathrm{~g} \mathrm{ha}^{-1}\right)$, diuron $\left(1250 \mathrm{~g} \mathrm{ha}^{-1}\right)$, Smetolachlor $\left(768 \mathrm{~g} \mathrm{ha}^{-1}\right)$, clomazone $\left(1000 \mathrm{~g} \mathrm{ha}^{-1}\right)$, fomesafen + prometryne $\left(625+1250 \mathrm{~g} \mathrm{ha}^{-1}\right)$, fomesafen + diuron $\left(625+1250 \mathrm{~g} \mathrm{ha}^{-1}\right)$, fomesafen + S-metolachlor $\left(625+768 \mathrm{~g} \mathrm{ha}^{-1}\right)$, fomesafen + clomazone $(625+1000$ $\left.\mathrm{g} \mathrm{ha}^{-1}\right)$, fomesafen + clomazone + diuron $\left(625+1000+1250 \mathrm{~g} \mathrm{ha}^{-1}\right)$, and fomesafen + clomazone + prometryne $\left(625+1000+1250 \mathrm{~g} \mathrm{ha}^{-1}\right)$, plus an untreated control. Applications of diuron showed the greatest persistence, causing the largest carryover effects for the three crops evaluated. The other treatments showed residual effects or affected crop development when sowings were performed up to 70 days after application. At later periods no significant damage was observed.
\end{abstract}

Keywords: Carryover. Phytointoxication. Persistence. Bioassay.

\section{ATIVIDADE RESIDUAL DE HERBICIDAS APLICADOS NO ALGODOEIRO SOBRE CULTURAS SEMEADAS EM SUCESSÃO}

RESUMO - Herbicidas com alta persistência no solo podem causar problemas em culturas semeadas em sucessão a sua aplicação. Desta forma, o objetivo deste trabalho foi estimar, em condições de casa-devegetação, o período de tempo seguro após aplicações em pré-emergência de herbicidas utilizados no algodoeiro (isolados ou em misturas) sobre culturas semeadas em sucessão (feijoeiro, milho e soja). O delineamento experimental utilizado foi o inteiramente casualizado, em arranjo fatorial $(5 \times 11)+1$, com cinco repetições. Em cada experimento (cultura), os tratamentos foram constituídos pela combinação de intervalos de tempo entre aplicação do herbicida e a semeadura das culturas $(280,210,140,70$ e 0 dia, antes da semeadura das culturas) e onze tratamentos com herbicidas: fomesafen $\left(625 \mathrm{~g} \mathrm{ha}^{-1}\right)$ prometryne $\left(1250 \mathrm{~g} \mathrm{ha}^{-1}\right)$, diuron (1250 $\left.\mathrm{g} \mathrm{ha}^{-1}\right)$, s-metolachlor $\left(768 \mathrm{~g} \mathrm{ha}^{-1}\right)$, clomazone $\left(1000 \mathrm{~g} \mathrm{ha}^{-1}\right)$, fomesafen + prometryne $\left(625+1250 \mathrm{~g} \mathrm{ha}^{-1}\right)$, fomesafen + diuron $\left(625+1250 \mathrm{~g} \mathrm{ha}^{-1}\right)$, fomesafen $+\mathrm{s}$-metolachlor $\left(625+768 \mathrm{~g} \mathrm{ha}^{-1}\right)$, fomesafen + clomazone $\left(625+1000 \mathrm{~g} \mathrm{ha}^{-1}\right)$, fomesafen + clomazone + diuron $\left(625+1000+1250 \mathrm{~g} \mathrm{ha}^{-1}\right)$ e fomesafen + clomazone + prometryne $\left(625+1000+1250 \mathrm{~g} \mathrm{ha}^{-1}\right)$ acrescidos de uma testemunha sem aplicação de herbicidas. Constatouse que as aplicações dos tratamentos contendo diuron apresentaram maior persistência, causando maior efeito carryover para as três culturas. Os demais tratamentos apresentaram efeito residual ou comprometeram o desenvolvimento das culturas quando as semeaduras foram realizadas até 70 dias após as aplicações, nos períodos superiores não foram observados danos significativos.

Palavras-chave: Carryover. Fitointoxicação. Persistência. Bioensaio.

\footnotetext{
*Corresponding Author

${ }^{1}$ Received for publication in $07 / 17 / 2015$; accepted in $12 / 21 / 2015$.

Paper extracted from the master thesis of the first author.

${ }^{2}$ Center for Advanced Studies in Weed Research, Agronomy Departament, Universidade Estadual de Maringá, Maringá, PR, Brazil; eliezer.gheno@gmail.com, rubem.oliveirajr@gmail.com, constantin@teracom.com.br, hudsontakano@gmail.com,
} alexandregemelli@gmail.com. 


\section{INTRODUCTION}

Brazil is one of the largest producers of beans, corn, and soybeans, currently occupying first, third, and second position respectively for production of these crops worldwide. During the 2014/2015 growing season, the country cultivated about 3,173.9 hectares of beans, producing approximately 3,339.8 tons. For corn, 15,165.9 hectares were grown with a total production of $78,985.2$ tons. As for soybeans, the country produced $94,280.5$ tons from $31,504.2$ hectares in the last growing season (CONAB, 2015).

These three crops are prominent in the Brazilian Savannah, especially corn and soybeans. Bean cultivation with irrigation has also increased annually (FILHO et al., 2004; NUNES et al., 2011; TORRES et al., 2013). The Savannah region also produces cotton and it is common to observe beans, corn, and soybeans succeeding the cultivation of cotton.

Cotton production depends on interactions among several biotic and abiotic variables (BELTRÃO et al., 2001). Among biotic factors, weeds are very important to crop management, whether because of damage caused to yield when they are not controlled or because of the impacts of the control methods (WEBSTER et al., 2009).

Chemical control with herbicides is an important tool in the large-scale cultivation of cotton. The use of herbicides at preemergence is already widespread among large cotton farmers, especially because of the effect weeds may have on crop yield potential when both coexist at the beginning of the cycle (INOUE et al., 2013). However, herbicides with long soil persistence, as is the case for some used at preemergence for cotton, might pose risks such as the contamination of the water table (BRIGHENTI et al., 2002) and the phytointoxication of crops sown in succession, also known as carryover (FERRI; VIDAL, 2003).

In Brazil, fomesafen is registered as a postemergence herbicide for soybean and bean crops for the control of broad-leaved weeds such as Amaranthus spp., Bidens spp., Euphorbia heterophylla, and Ipomoea spp. among others. Recently, its registration was extended for use with preemergence cotton for the control of Physalis angulata and Amaranthus deflexus, used at a rate of $375 \mathrm{~g} \mathrm{ha}^{-1}$ (OLIVEIRA NETO, 2015). However, studies by Cobucci et al. (1998), Artuzi and Contiero (2006), and Dan et al. (2012) have shown that residual fomesafen activity can cause injury to species sown up to 112 days after its application. Hence, it is necessary to evaluate the safety characteristics of this and other preemergent herbicides for crops grown in succession to cotton so as to safely support their use recommendations.

The aim of this study is to estimate the period of time after preemergence applications of fomesafen (isolated or in mixtures) after which beans, corn, and soybeans can be safely sown without causing phytointoxication of these crops.

\section{MATERIAL AND METHODS}

The experiments were conducted in a greenhouse at the Irrigation Training Center (CTI) of the Universidade Estadual de Maringá (UEM) $\left(23^{\circ} 24^{\prime} 12^{\prime \prime} \mathrm{S}\right.$ and $51^{\circ} 56^{\prime} 24^{\prime \prime} \mathrm{W}$, altitude $\left.560 \mathrm{~m}\right)$. Tests were carried out from $11 / 29 / 12$ to $10 / 18 / 2013$.

The soil material used was dried, sieved, and placed in $3 \mathrm{dm}^{3}$ plastic pots (without external coating), which were considered as experimental units. Soil analysis revealed the following chemical and physical characteristics: water $\mathrm{pH}$ of $6.30 ; 4.61$ cmolc of $\mathrm{H}^{+}+\mathrm{Al}^{+3} \mathrm{dm}^{-3}$ of soil; $4.90 \mathrm{cmolc} \mathrm{dm}^{-3}$ of $\mathrm{Ca}^{+2} ; 1.70 \mathrm{cmolc} \mathrm{dm}^{-3}$ of $\mathrm{Mg}^{+2} ; 0.56 \mathrm{cmolc} \mathrm{dm}^{-3}$ of $\mathrm{K}+; 15.74 \mathrm{mg} \mathrm{dm}^{-3}$ of $\mathrm{P} ; 16.93 \mathrm{~g} \mathrm{dm}^{-3}$ of C; $190 \mathrm{~g} \mathrm{~kg}^{-}$ ${ }^{1}$ of coarse sand; $90 \mathrm{~g} \mathrm{~kg}^{-1}$ of fine sand; $140 \mathrm{~g} \mathrm{~kg}^{-1}$ of silt; and $580 \mathrm{~g} \mathrm{~kg}^{-1}$ of clay.

Three different crops were evaluated, for which three distinct experiments were carried out simultaneously. The bean, corn, and soybean varieties used were Tangará, $2 \mathrm{~B} 710 \mathrm{RR}^{\circledR}$, and $\mathrm{BMX}$ Potência $R^{\circledR}{ }^{\circledR}$ respectively. The experimental design was entirely randomized in a factorial scheme $(5 \times 11)$ +1 with five replicates. For each experiment, treatments varied in the time period between herbicide application and sowing $(280,210,140,70$, and 0 days before sowing - DAS) in eleven different treatments with herbicides (Table 1), as well as an untreated control. The basic premise was to estimate the period of time needed to safely sow the crops after the use of the herbicide treatments at cotton preemergence.

Applications were carried out using a $\mathrm{CO}_{2}$ backpack sprayer at constant pressure with three XR110.02 flat fan nozzles at a pressure of $2.0 \mathrm{kgf} \mathrm{cm}^{-2}$. These application conditions provided the equivalent of $200 \mathrm{~L} \mathrm{ha}^{-1}$ spray volume. The soil and climate conditions at the time of application are presented in Table 2.

After each herbicide application, pots were watered using an automatic irrigation system. However, a different precipitation accumulation was simulated for each period of time. These accumulation values were established from average rainfall data for Santa Helena de Goiás (GO) (rainfall data were collected from the meteorological station at the Universidade de Rio Verde - UniRV). The conditions for cotton sowing on the first of December were simulated. The water supply was estimated for $280,210,140,70$, and 0 days after herbicide application (Table 3 ) in order to simulate average field conditions in the greenhouse. 
E. A. GHENO et al.

Table 1. Herbicides and their respective rates evaluated in the experiments. Maringá-PR/2013

\begin{tabular}{|c|c|c|}
\hline Herbicides & Rate $\left(\mathrm{g} \mathrm{ha}^{-1}\right)$ & Abbreviations \\
\hline fomesafen & 625 & FOM \\
\hline prometryne & 1250 & PRO \\
\hline diuron & 1250 & DIU \\
\hline S-metolachlor & 768 & S-MET \\
\hline clomazone & 1000 & CLO \\
\hline fomesafen + prometryne & $625+1250$ & $\mathrm{FOM}+\mathrm{PRO}$ \\
\hline fomesafen + diuron & $625+1250$ & $\mathrm{FOM}+\mathrm{DIU}$ \\
\hline fomesafen + S-metolachlor & $625+768$ & $\mathrm{FOM}+\mathrm{S}-\mathrm{MET}$ \\
\hline fomesafen + clomazone & $625+1000$ & $\mathrm{FOM}+\mathrm{CLO}$ \\
\hline fomesafen + clomazone + diuron & $450+1000+1250$ & $\mathrm{FOM}+\mathrm{CLO}+\mathrm{DIU}$ \\
\hline fomesafen + clomazone + prometryne & $450+1000+1250$ & $\mathrm{FOM}+\mathrm{CLO}+\mathrm{PRO}$ \\
\hline
\end{tabular}

Table 2. Soil and climate conditions at the time of application with different herbicides applied at preemergence. Maringá$\mathrm{PR} / 2013$.

\begin{tabular}{lccccc}
\hline & $1^{\text {st }}$ Applic. & $2^{\text {nd }}$ Applic. & $3^{\text {rd }}$ Applic. & $4^{\text {th }}$ Applic. & $5^{\text {th }}$ Applic. \\
$(20$ DAS $)$ & $(00$ DAS $)$ \\
\hline RH $(\%)$ & 60 & 80 & 65 & 65 & 61 \\
Temp. $\left({ }^{\circ} \mathrm{C}\right)$ & 240 DAS $)$ & 20 & 25 & 24 & 24 \\
W.S. $\left(\mathrm{km} \mathrm{h}^{-1}\right)$ & 2.8 & 2.5 & 2.0 & 0.9 & 1.2 \\
Soil moisture & Humid & Humid & Humid & Humid & Humid \\
\hline
\end{tabular}

RH: Relative Humidity; Temp: Temperature; W.S.: Wind speed; DAS: Days before sowing.

Table 3. Simulated precipitation $(\mathrm{mm})$ and precipitation by irrigation interval ${ }^{1 /}(\mathrm{mm})$ for different periods between the application of preemergence herbicides and crops sown in succession. Maringá-PR/2013.

\begin{tabular}{ccc}
\hline Period & Simulated rainfall $(\mathrm{mm})$ & Precipitation by irrigation interval $(\mathrm{mm})$ \\
\hline 0 DAS & 0 & 0 \\
70 DAS & 596 & 17.03 \\
140 DAS & 1090 & 15.57 \\
210 DAS & 1190 & 11.33 \\
280 DAS & 1230 & 8.79 \\
\hline
\end{tabular}

1/Frequency of irrigation interval: 48 hours.

After herbicide application, crops were sown simultaneously for all treatments on 09/19/2013 with four seeds at 2-3 cm deep per pot. Pots were kept weed free to ensure only herbicides affected the crop development.

Phytointoxication of bean, corn, and soybean plants was evaluated at seven and 21 days after emergence (DAE) using a visual scale (EWRC, 1964). At 23 DAE, shoots were collected, placed in paper bags dried in an oven at $65{ }^{\circ} \mathrm{C}$ until constant weight was reached. Dry matter accumulation was expressed in grams per plant.

Data were subjected to variance analysis. When there were significant differences among herbicides or sowing periods, the Scott-Knott $(p \leq 0.05)$ test was applied. Comparisons between the different treatments and the untreated control were carried out using the Dunnett test $(\mathrm{p} \leq 0.05)$.

Variables related to dry matter accumulation of all three crops were analyzed through regression using the Mitscherlich model, $\mathrm{Y}=\mathrm{Z} *(\exp (-\mathrm{H} *$ $\mathrm{X})+\mathrm{U}$, in which $\mathrm{Y}$ is the dry matter accumulation expressed in $g$ per plant ${ }^{-1} ; \mathrm{Z}, \mathrm{H}$, and $\mathrm{U}$ are equation parameters: $Z$ is the difference between the accumulation (in $\mathrm{g} \mathrm{plant}^{-1}$ ) at $0 \mathrm{DAA}$ and maximum accumulation (in $\mathrm{g}$ plant ${ }^{-1}$ ); $\mathrm{H}$ is the curve concavity; $U$ is the maximum accumulation (in $g$ plant ${ }^{-1}$ ), and $\mathrm{X}$ refers to the period (days) between herbicide application and the sowing of the crops.

Based on fitted regression equations, the periods at which treatments did not affect dry matter accumulation were determined, adopting a tolerance level of $5 \%$ compared to the dry matter accumulation observed in the control.

\section{RESULTS AND DISCUSSION}

\section{Experiment 1 - Beans}

Isolated applications of fomesafen and Smetolachlor did not cause injury to bean plants at any time interval between application and sowing (Table 4). On the other hand, isolated applications of prometryne, diuron, and clomazone caused high levels of phytointoxication. Injuries were observed for sowings carried out up to 70 days after the application of prometryne and diuron. 
E. A. GHENO et al.

Table 4. Results of visual evaluation of bean phytointoxication (EWRC, 1964) $)^{1 /}$ performed at 7 and 21 DAE, after simulating different periods between herbicide application at preemergence and crop sowing.

\begin{tabular}{|c|c|c|c|c|c|c|c|c|c|c|}
\hline \multirow{3}{*}{ Herbicides } & \multicolumn{10}{|c|}{ Period of time (days) between application and bean sowing } \\
\hline & \multicolumn{5}{|c|}{$7 \mathrm{DAE}$} & \multicolumn{5}{|c|}{$21 \mathrm{DAE}$} \\
\hline & 0 & 70 & 140 & 210 & 280 & 0 & 70 & 140 & 210 & 280 \\
\hline FOM & 1.0 & 1.0 & 1.0 & 1.0 & 1.0 & 1.0 & 1.0 & 1.0 & 1.0 & 1.0 \\
\hline PRO & 3.2 & 1.6 & 1.0 & 1.0 & 1.0 & 3.0 & 1.0 & 1.0 & 1.0 & 1.0 \\
\hline DIU & 4.4 & 2.2 & 1.0 & 1.0 & 1.0 & 7.4 & 4.2 & 1.0 & 1.0 & 1.0 \\
\hline S-MET & 1.0 & 1.0 & 1.0 & 1.0 & 1.0 & 1.0 & 1.0 & 1.0 & 1.0 & 1.0 \\
\hline $\mathrm{CLO}$ & 3.2 & 1.0 & 1.0 & 1.0 & 1.0 & 3.6 & 1.0 & 1.0 & 1.0 & 1.0 \\
\hline $\mathrm{FOM}+\mathrm{PRO}$ & 2.0 & 1.4 & 1.0 & 1.0 & 1.0 & 3.6 & 1.0 & 1.0 & 1.0 & 1.0 \\
\hline $\mathrm{FOM}+\mathrm{DIU}$ & 3.6 & 1.4 & 1.0 & 1.0 & 1.0 & 6.8 & 3.8 & 1.0 & 1.0 & 1.0 \\
\hline FOM + S-MET & 1.4 & 1.0 & 1.0 & 1.0 & 1.0 & 1.0 & 1.0 & 1.0 & 1.0 & 1.0 \\
\hline $\mathrm{FOM}+\mathrm{CLO}$ & 3.8 & 1.0 & 1.0 & 1.0 & 1.0 & 4.8 & 1.0 & 1.0 & 1.0 & 1.0 \\
\hline $\mathrm{FOM}+\mathrm{CLO}+\mathrm{DIU}$ & 4.2 & 4.4 & 2.0 & 1.0 & 1.0 & 7.8 & 6.8 & 3.8 & 1.0 & 1.0 \\
\hline $\mathrm{FOM}+\mathrm{CLO}+\mathrm{PRO}$ & 3.8 & 1.2 & 1.0 & 1.0 & 1.0 & 6.8 & 2.2 & 1.0 & 1.0 & 1.0 \\
\hline
\end{tabular}

${ }^{1 /}$ Scale E.W.R.C., where $1.0=$ no symptoms and $9.0=100 \%$ plant death.

Mixtures consisting of prometryne, diuron, and clomazone caused higher levels of phytointoxication, affecting plants sown up to 140 DAA (fomesafen + clomazone + diuron). Thus, it is possible to infer that injuries observed in the combination of fomesafen with other herbicides (except for S-metolachlor) should not be attributed to fomesafen, but to the other active ingredients comprising these treatments. Symptoms varied from pronounced chlorosis next to leaf veins to puckering, purpling, and necrosis of the foliar limb.

Treatments with diuron (isolated or in combination) and the mixture fomesafen + clomazone + prometryne significantly reduced dry matter accumulation in bean plants by up to $92 \%$ at 0 DAA (Table 5).

Table 5. Dry matter accumulation of bean shoots in $\mathrm{g}_{\text {plant }}{ }^{-1}$ after simulating different time periods between herbicide application at preemergence and crop sowing. Maringá-PR/2013.

\begin{tabular}{|c|c|c|c|c|c|c|c|c|c|c|}
\hline \multirow{3}{*}{$\begin{array}{c}\text { Herbicides } \\
\text { FOM }\end{array}$} & \multicolumn{10}{|c|}{ Period of time (days) between application and sowing of beans } \\
\hline & \multicolumn{2}{|c|}{0} & \multicolumn{2}{|c|}{70} & \multicolumn{2}{|c|}{140} & \multicolumn{2}{|c|}{210} & \multicolumn{2}{|c|}{280} \\
\hline & 0.49 & $\mathrm{Aa}$ & 0.60 & $\mathrm{Aa}$ & 0.59 & Aa & 0.58 & $\mathrm{Aa}$ & 0.58 & Aa \\
\hline PRO & 0.38 & $\mathrm{Aa}$ & 0.58 & $\mathrm{Aa}$ & 0.55 & Aa & 0.57 & $\mathrm{Aa}$ & 0.57 & Aa \\
\hline DIU & 0.06 & $\mathrm{Cb}^{-}$ & 0.28 & $\mathrm{Bb}^{-}$ & 0.53 & $\mathrm{Aa}$ & 0.59 & $\mathrm{Aa}$ & 0.60 & Aa \\
\hline S-MET & 0.57 & $\mathrm{Aa}$ & 0.55 & $\mathrm{Aa}$ & 0.60 & $\mathrm{Aa}$ & 0.56 & $\mathrm{Aa}$ & 0.55 & Aa \\
\hline CLO & 0.48 & $\mathrm{Aa}$ & 0.56 & $\mathrm{Aa}$ & 0.60 & $\mathrm{Aa}$ & 0.57 & $\mathrm{Aa}$ & 0.56 & $\mathrm{Aa}$ \\
\hline $\mathrm{FOM}+\mathrm{PRO}$ & 0.46 & $\mathrm{Aa}$ & 0.56 & $\mathrm{Aa}$ & 0.58 & $\mathrm{Aa}$ & 0.59 & $\mathrm{Aa}$ & 0.59 & Aa \\
\hline $\mathrm{FOM}+\mathrm{DIU}$ & 0.14 & $\mathrm{Bb}^{-}$ & 0.47 & $\mathrm{Aa}$ & 0.45 & $\mathrm{Aa}$ & 0.53 & $\mathrm{Aa}$ & 0.45 & Aa \\
\hline FOM + S-MET & 0.51 & $\mathrm{Aa}$ & 0.57 & $\mathrm{Aa}$ & 0.59 & Aa & 0.58 & $\mathrm{Aa}$ & 0.57 & $\mathrm{Aa}$ \\
\hline $\mathrm{FOM}+\mathrm{CLO}$ & 0.42 & $\mathrm{Aa}$ & 0.61 & $\mathrm{Aa}$ & 0.60 & Aa & 0.57 & $\mathrm{Aa}$ & 0.62 & Aa \\
\hline $\mathrm{FOM}+\mathrm{CLO}+\mathrm{DIU}$ & 0.05 & $\mathrm{Cb}^{-}$ & 0.23 & $\mathrm{Bb}^{-}$ & 0.43 & Aa & 0.59 & $\mathrm{Aa}$ & 0.45 & $\mathrm{Aa}$ \\
\hline $\mathrm{FOM}+\mathrm{CLO}+\mathrm{PRO}$ & 0.15 & $\mathrm{Bb}^{-}$ & 0.55 & $\mathrm{Aa}$ & 0.55 & $\mathrm{Aa}$ & 0.56 & $\mathrm{Aa}$ & 0.56 & $\mathrm{Aa}$ \\
\hline Untreated control & \multicolumn{10}{|c|}{0.60} \\
\hline LSD additional control & \multicolumn{10}{|c|}{0.28} \\
\hline $\mathrm{CV}(\%)$ & \multicolumn{10}{|c|}{27.6} \\
\hline
\end{tabular}

Different from untreated control by the Dunnet test at $5 \%$ probability: ${ }^{-}$significantly lower and ${ }^{+}$significantly higher; Means followed by the same letter, uppercase in the line and lowercase in the column, do not differ by the Scott-Knott test at 5\% probability.

At 70 days between application and crop sowing, only diuron alone or in combination with fomesafen + clomazone affected dry matter accumulation. However, these treatment caused a lower reduction in mass compared to 0 DAA, when dry matter was reduced $57 \%$ on average, in relation to the control. Despite the fact that visual symptoms of phytointoxication were observed for the fomesafen + clomazone + diuron mixture at 140 DAA, these injuries did not result in significant differences in dry matter accumulation and no treatments were negatively affected in dry matter accumulation when sowing was more than 140 days after herbicide application.

Lamego et al. (2011) and Fernandes et al. (2011) observed high selectivity of S-metolachlor when it was applied to bean at preemergence at rates of up to $1920 \mathrm{~g} \mathrm{ha}^{-1}$. Small injuries were noticed after application, but they not affect crop yield components in either experiment. Takano et al. (2013) found differences in the selectivity of clomazone $\left(1000 \mathrm{~g} \mathrm{ha}^{-1}\right)$ applied at preemergence between cultivars from the carioca group variety. The Tangará cultivar evaluated in the study is assumed to better tolerate this herbicide, explaining the lack of damage observed. 
The most interesting aspect of this experiment for growers is whether significant injuries can occur that may hinder crop development, and also how many days after the application of herbicide treatments at preemergence of cotton must elapse before beans may be sown without stunting. Based on the equations showing significance by the Mitscherlich model, periods $\geq 207$ days are sufficient for diuron (1250 $\left.\mathrm{g} \mathrm{ha}^{-1}\right)$ not to affect bean development, with a tolerance of up to $5 \%$ negative effects (Figure 1).

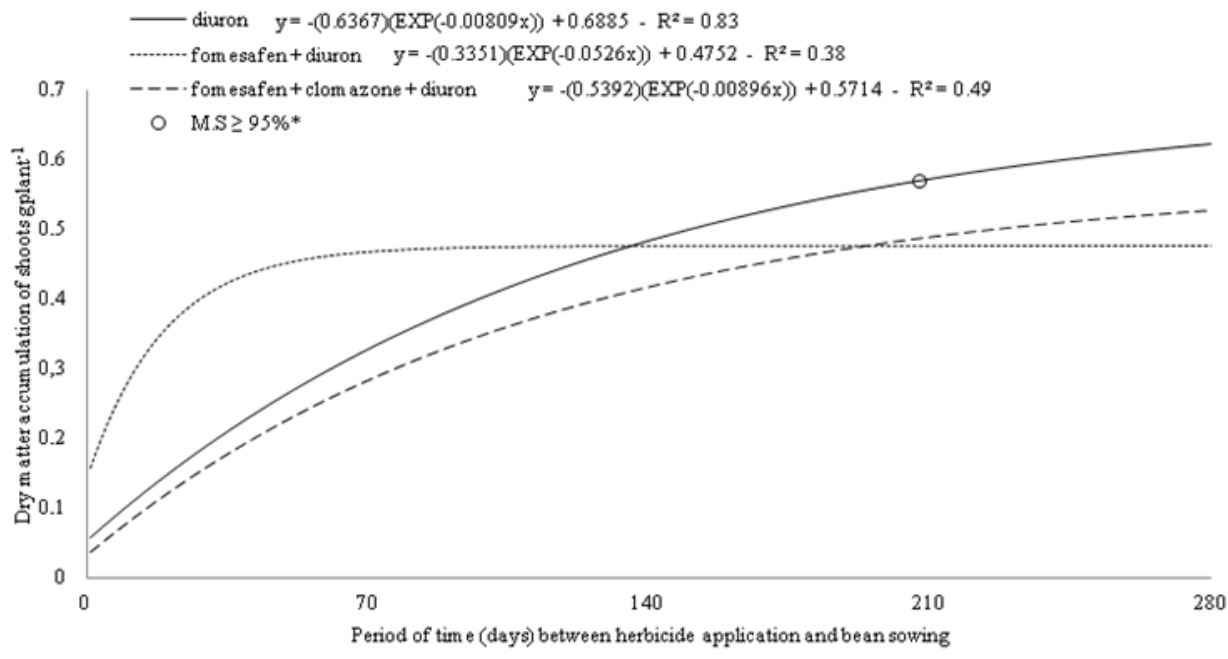

*Days after application (207) in which the dry matter accumulation of bean shoots was $\geq 95 \%$ compared to the untreated control.

Figure 1. Dry matter accumulation of bean shoots after increasing periods between the application of preemergence herbicides and sowing. Maringá-PR/2013.

It was not possible to determine a safe period for sowing beans subsequent to the application of mixtures of fomesafen + diuron and fomesafen + clomazone + diuron since the minimum reduction in dry weight measured for these treatments in relation to the control was 21 and $12 \%$ respectively for the longest period between application and crop sowing (280 DAA). In summary, the safe period for sowing beans exceeds 280 days when these herbicides are applied.

There is was no detrimental effect on beans sowed after treatments with fomesafen alone or in combination with prometryne and S-metolachlor, or for clomazone alone or in combination with fomesafen when the herbicides were applied at cotton preemergence. However, a 70-day period is necessary after the application of fomesafen + clomazone + prometryne in order to sow the crop without negative effects.

\section{Experiment 2 - Corn}

Extremely serious injuries were observed, including plant death, in all treatments with fomesafen and in applications of diuron or clomazone alone (Table 6). Applications of prometryne and S-metolachlor alone resulted in low levels of intoxication to corn plants. The visual evaluation of injuries to corn plants sowed 70 days after herbicide application revealed greater injuries for both triple herbicide associations as well as for combinations of fomesafen + diuron and fomesafen
+ clomazone. Only the application of fomesafen + clomazone + diuron developed injury levels. The other treatments caused only relatively minor injuries. When corn was sown after a period equal to or exceeding 140 days after herbicide application, phytointoxication symptoms were minor or not present.

Because of high toxicity when fomesafen was applied, only prometryne or S-metolachlor alone did not cause a reduction in the accumulation of shoot dry matter when applied at sowing (Table 7). After a 70-day period between application and sowing, only diuron combined with fomesafen and fomesafen combined with clomazone resulted in reduced dry matter accumulation relative to the control, with reductions in shoot dry weight of 35 and $74 \%$ respectively.

There were no differences between treatments from 140 days between application and sowing onwards in the accumulation of dry matter. Hence, the residual levels of herbicides in the soil were not sufficient to cause a reduction in dry matter, although some herbicides caused phytointoxication symptoms at 140 DAA.

Santos et al. (2012) did not observe phytointoxication or a reduction in height or dry matter of corn plants when they applied up to four times the recommended rate of S-metolachlor at preemergence of cotton within 120 days prior to corn sowing. Additionally, tolerant plants, including corn and soybeans, can metabolize enough chloroacetamide to prevent the accumulation and 
persistence of phytointoxication levels (LIEBL, 1995).

Fomesafen is considered a weak acid herbicide ( $\mathrm{pKa}$ 2.83) (RODRIGUES; ALMEIDA, 2011), usually found in its neutral form when the environmental $\mathrm{pH}$ is lower than its $\mathrm{pKa}$ and found in its anionic form when the is higher than its $\mathrm{pKa}$. The soil used had a $\mathrm{pH}$ of 6.3 in water. Thus, because fomesafen was predominantly in the anionic form low sorption to the soil would have occurred, allowing a greater degree of leaching (OLIVEIRA et al., 2005) and decreasing its concentration in the soil. According to Andrade et al. (2011), fomesafen can contaminate the water table due to its high leaching potential. It is relevant to mention that the simulated precipitation for the 70-day time period after herbicide application was $596 \mathrm{~mm}$. In addition, higher $\mathrm{pH}$ values may increase the solubility and bioavailability of fomesafen (WEBER, 1993).

Table 6. Results of visual evaluations of corn phytointoxication (EWRC, 1964) $)^{1 /}$ carried out at 7 and 21 DAE, after simulating different time periods between herbicide application at preemergence and crop sowing. Maringá-PR/2013.

\begin{tabular}{ccccccccccc}
\hline \multirow{3}{*}{ Herbicides } & \multicolumn{9}{c}{ Period of time (days) between application and $\mathrm{RR}^{\circledR}$ corn sowing } \\
\cline { 2 - 12 } & 0 & 70 & 140 & 210 & 280 & 0 & 70 & 140 & 210 & 280 \\
\cline { 2 - 10 }$y$ & 8.0 & 3.2 & 1.4 & 1.0 & 1.0 & 9.0 & 1.4 & 1.0 & 1.0 & 1.0 \\
FOM & 2.4 & 3.8 & 1.0 & 1.0 & 1.0 & 1.8 & 1.2 & 1.0 & 1.0 & 1.0 \\
PRO & 2.6 & 2.4 & 1.0 & 1.0 & 1.0 & 7.8 & 1.0 & 1.0 & 1.0 & 1.0 \\
DIU & 2.4 & 1.6 & 1.0 & 1.0 & 1.0 & 1.4 & 1.0 & 1.0 & 1.0 & 1.0 \\
S-MET & 4.0 & 2.0 & 1.2 & 1.0 & 1.0 & 8.8 & 1.0 & 1.0 & 1.0 & 1.0 \\
CLO & 7.8 & 3.2 & 1.8 & 1.0 & 1.0 & 8.8 & 1.4 & 1.0 & 1.0 & 1.0 \\
FOM + PRO & 8.0 & 4.4 & 1.2 & 1.0 & 1.0 & 9.0 & 4.2 & 1.0 & 1.0 & 1.0 \\
FOM + DIU & 8.0 & 3.4 & 1.6 & 1.0 & 1.0 & 9.0 & 1.4 & 1.0 & 1.0 & 1.0 \\
FOM + S-MET & 6.8 & 3.8 & 1.8 & 1.0 & 1.0 & 8.8 & 4.2 & 1.2 & 1.0 & 1.0 \\
FOM + CLO & 6.8 & 4.8 & 2.2 & 1.0 & 1.0 & 9.0 & 6.6 & 1.8 & 1.0 & 1.0 \\
FOM + CLO + DIU & 7.2 & 3.0 & 1.2 & 1.0 & 1.0 & 8.6 & 4.0 & 1.0 & 1.0 & 1.0 \\
FOM + CLO + PRO & & &
\end{tabular}

${ }^{1 /}$ Scale E.W.R.C., where $1.0=$ no symptoms and $9.0=100 \%$ of plant death.

Table 7. Dry matter accumulation of $\mathrm{RR}^{\circledR}$ corn shoots in $\mathrm{g}$ plant ${ }^{-1}$ after simulating different time periods between herbicide application at preemergence and crop sowing. Maringá-PR/2013.

\begin{tabular}{|c|c|c|c|c|c|c|c|c|c|c|}
\hline \multirow{3}{*}{$\begin{array}{c}\text { Herbicides } \\
\text { FOM }\end{array}$} & \multicolumn{10}{|c|}{ Period of time (days) between application and sowing of $\mathrm{RR}^{(B)}$ corn } \\
\hline & \multicolumn{2}{|c|}{0} & \multicolumn{2}{|c|}{70} & \multicolumn{2}{|c|}{140} & \multicolumn{2}{|c|}{210} & \multicolumn{2}{|c|}{280} \\
\hline & 0.00 & $\mathrm{Bb}^{-}$ & 0.56 & $\mathrm{Aa}$ & 0.54 & $\mathrm{Aa}$ & 0.55 & $\mathrm{Aa}$ & 0.54 & $\mathrm{Aa}$ \\
\hline PRO & 0.41 & $\mathrm{Ba}$ & 0.57 & $\mathrm{Aa}$ & 0.57 & $\mathrm{Aa}$ & 0.55 & $\mathrm{Aa}$ & 0.56 & $\mathrm{Aa}$ \\
\hline DIU & 0.06 & $\mathrm{Bb}^{-}$ & 0.56 & $\mathrm{Aa}$ & 0.55 & Aa & 0.53 & Aa & 0.55 & Aa \\
\hline S-MET & 0.50 & $\mathrm{Aa}$ & 0.57 & $\mathrm{Aa}$ & 0.56 & $\mathrm{Aa}$ & 0.53 & Aa & 0.54 & Aa \\
\hline CLO & 0.00 & $\mathrm{Bb}^{-}$ & 0.57 & $\mathrm{Aa}$ & 0.52 & $\mathrm{Aa}$ & 0.52 & $\mathrm{Aa}$ & 0.53 & $\mathrm{Aa}$ \\
\hline $\mathrm{FOM}+\mathrm{PRO}$ & 0.00 & $\mathrm{Bb}^{-}$ & 0.55 & $\mathrm{Aa}$ & 0.53 & $\mathrm{Aa}$ & 0.57 & $\mathrm{Aa}$ & 0.58 & $\mathrm{Aa}$ \\
\hline $\mathrm{FOM}+\mathrm{DIU}$ & 0.00 & $\mathrm{Cb}^{-}$ & 0.38 & $\mathrm{Bb}^{-}$ & 0.58 & $\mathrm{Aa}$ & 0.53 & $\mathrm{Aa}$ & 0.58 & $\mathrm{Aa}$ \\
\hline $\mathrm{FOM}+\mathrm{S}-\mathrm{MET}$ & 0.00 & $\mathrm{Bb}^{-}$ & 0.56 & $\mathrm{Aa}$ & 0.55 & $\mathrm{Aa}$ & 0.53 & $\mathrm{Aa}$ & 0.54 & $\mathrm{Aa}$ \\
\hline $\mathrm{FOM}+\mathrm{CLO}$ & 0.00 & $\mathrm{Bb}^{-}$ & 0.56 & $\mathrm{Aa}$ & 0.53 & $\mathrm{Aa}$ & 0.59 & $\mathrm{Aa}$ & 0.56 & $\mathrm{Aa}$ \\
\hline $\mathrm{FOM}+\mathrm{CLO}+\mathrm{DIU}$ & 0.00 & $\mathrm{Cb}^{-}$ & 0.15 & $\mathrm{Bc}^{-}$ & 049 & $\mathrm{Aa}$ & 0.52 & $\mathrm{Aa}$ & 0.57 & $\mathrm{Aa}$ \\
\hline $\mathrm{FOM}+\mathrm{CLO}+\mathrm{PRO}$ & 0.00 & $\mathrm{Bb}^{-}$ & 0.57 & $\mathrm{Aa}$ & 0.49 & $\mathrm{Aa}$ & 0.58 & $\mathrm{Aa}$ & 0.54 & $\mathrm{Aa}$ \\
\hline Untreated control & \multicolumn{10}{|c|}{0.58} \\
\hline LSD additional control & \multicolumn{10}{|c|}{0.18} \\
\hline CV (\%) & \multicolumn{10}{|c|}{20.5} \\
\hline
\end{tabular}

Differ from untreated control by the Dunnet test at 5\% probability: ${ }^{-}$significantly lower and ${ }^{+}$significantly higher; Means followed by the same letter, uppercase in the line and lowercase in the column, do not differ by the Scott-Knott test at 5\% probability.

The mixtures fomesafen + diuron, fomesafen + clomazone + diuron can affect dry matter accumulation when sowing is carried out at periods shorter than 186 and 239 days respectively after herbicide application (Figure 2). Therefore, these periods of time should be observed when sowing corn after the application of the aforementioned mixtures. These results are in agreement with those of Inoue et al. (2011) who noticed that diuron (1600 $\left.\mathrm{g} \mathrm{ha}^{-1}\right)$ in an oxisol ( $\mathrm{pH}$ in $\mathrm{H}_{2} \mathrm{O}$ of $6.7 ; 438 \mathrm{~g} \mathrm{~kg}^{-1}$ of clay and $43 \mathrm{~g} \mathrm{dm}^{-3}$ of C) resulted in control levels of $80 \%$ of Brachiaria decumbens up to 54 DAA. It was considered slightly leachable in clayey soils (LIU et al., 1970) indicating its long persistence in this soil type. 


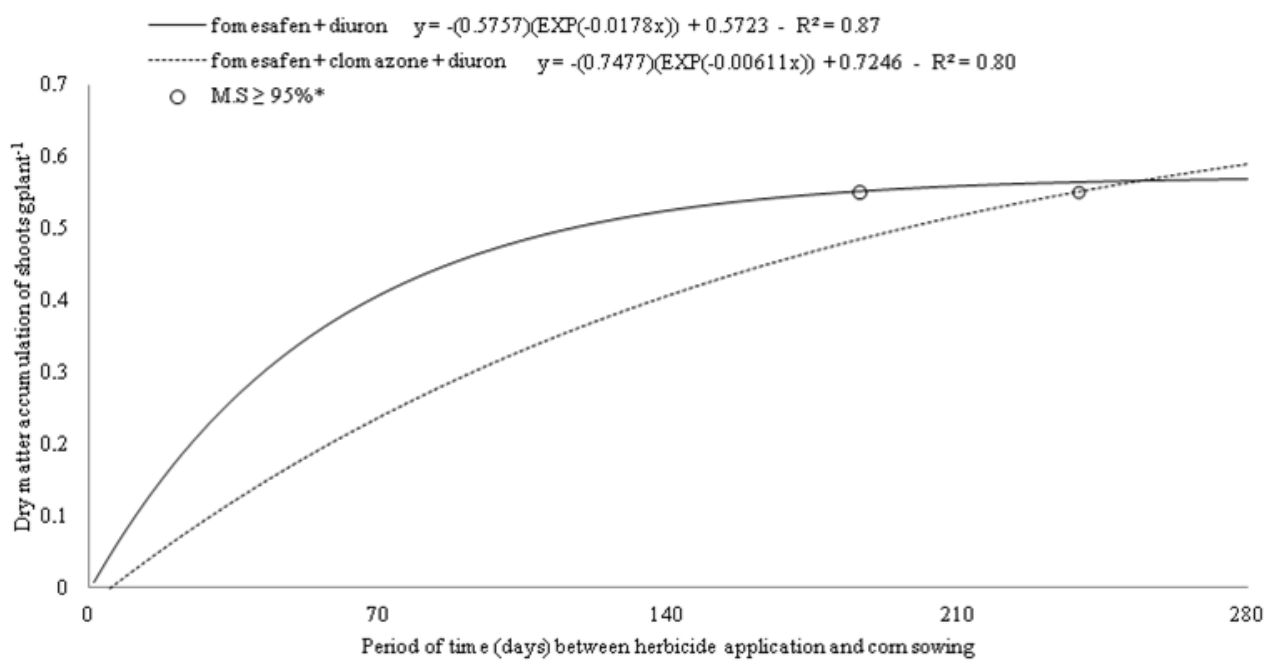

$*$ Days after application (fomesafen + diuron $=186$; fomesafen + clomazone + diuron $=239$ ) in which the dry matter accumulation of corn shoots was $\geq 95 \%$ compared to the untreated control.

Figure 2. Dry matter accumulation of corn shoots after increasing time periods between the application of preemergence herbicides and sowing. Maringá-PR/2013.

Isolated S-metolachlor was the only treatment not to stunt crop development when sowing was carried out immediately after application, considering the results of phytointoxication and dry matter of corn plants. This result was expected due to the selectivity of the active ingredient for the crop, which is registered for corn (RODRIGUES; ALMEIDA, 2011).

Although isolated prometryne did not affect dry matter significantly when compared to the control and the other herbicide treatments, dry matter accumulation was reduced compared to other time periods after application. Thus, it is important to observe a minimum period of 70 days before sowing corn after the application of prometryne as well as after using clomazone or diuron. Inoue et al. (2011) found that the application of clomazone (900 and $1100 \mathrm{~g} \mathrm{ha}^{-1}$ ) controlled $80 \%$ of $B$. decumbens up to 39 DAA. Studies conducted by Santos et al. (2003) indicated that clomazone applied to soybeans affected successive crops of wheat, oats, and barley because of its persistence in the soil, therefore requiring a minimum of 150 DAA before planting the subsequent crop.

For corn, a minimum of 70 days should elapse after applications of isolated fomesafen, fomesafen + prometryne and fomesafen $+\mathrm{S}$ metolachlor before planting. The crop should not be implemented at periods shorter than 140 DAA of fomesafen + clomazone and fomesafen + clomazone
+ prometryne.

\section{Experiment 3 - Soybeans}

Only the application of fomesafen or Smetolachlor alone did not cause initial phytointoxication symptoms in soybeans when plants were sown shortly after herbicide application (Table 8). However, prometryne or diuron treatments caused high levels of intoxication, and even the death of several plants. The other treatments presented similar symptoms, only varying in the intensity of the chlorosis observed on the foliar limb.

When sowing was carried out at 70 DAA, only treatments with diuron showed soil persistence that resulted in high levels of plant injury, especially in the combination of diuron with fomesafen + clomazone. After 140 DAA, injuries to soybean plants were no longer observed.

At 0 DAA, treatments with diuron significantly reduced dry matter accumulation, by up to $95 \%$ in comparison to the additional control (Table 9). Applications of prometryne alone or in combination with fomesafen + clomazone also affected dry matter accumulation, but at lower levels than those observed for treatments with diuron. The combination of fomesafen + prometryne did not affect dry matter accumulation significantly. The other treatments did not lead to significant reductions in dry matter accumulation. 
E. A. GHENO et al.

Table 8. Results of visual evaluations of soybean phytointoxication (EWRC, 1964) carried out at 7 and 21 DAE, after simulating different time periods between herbicide application at preemergence and crop sowing. Maringá-PR/2013.

\begin{tabular}{ccccccccccc}
\hline \multirow{3}{*}{ Herbicides } & \multicolumn{9}{c}{ Period of time (days) between application and $\mathrm{RR}^{\circledR}$ soybean sowing } \\
\cline { 2 - 11 } & 0 & 70 & 140 & 210 & 280 & 0 & 70 & 140 & 210 & 280 \\
\cline { 2 - 10 }$y$ & 1.0 & 1.0 & 1.0 & 1.0 & 1.0 & 1.6 & 1.0 & 1.0 & 1.0 & 1.0 \\
FOM & 2.6 & 1.8 & 1.0 & 1.0 & 1.0 & 5.4 & 1.0 & 1.0 & 1.0 & 1.0 \\
PRO & 1.2 & 1.2 & 1.0 & 1.0 & 1.0 & 8.6 & 3.8 & 1.0 & 1.0 & 1.0 \\
DIU & 1.0 & 1.0 & 1.0 & 1.0 & 1.0 & 1.0 & 1.0 & 1.0 & 1.0 & 1.0 \\
S-MET & 3.2 & 1.4 & 1.0 & 1.0 & 1.0 & 3.4 & 1.4 & 1.0 & 1.0 & 1.0 \\
CLO & 2.0 & 1.6 & 1.0 & 1.0 & 1.0 & 6.0 & 1.0 & 1.0 & 1.0 & 1.0 \\
FOM + PRO & 1.6 & 1.4 & 1.0 & 1.0 & 1.0 & 7.4 & 3.8 & 1.0 & 1.0 & 1.0 \\
FOM + DIU & 3.6 & 1.0 & 1.0 & 1.0 & 1.0 & 1.2 & 1.0 & 1.0 & 1.0 & 1.0 \\
FOM + S-MET & 1.6 & 1.0 & 1.0 & 1.0 & 1.0 & 2.6 & 1.0 & 1.0 & 1.0 & 1.0 \\
FOM + CLO & 2.2 & 1.0 & 1.0 & 1.0 & 1.0 & 8.5 & 7.0 & 1.0 & 1.0 & 1.0 \\
FOM + CLO + DIU & 2.8 & 1.6 & 1.0 & 1.0 & 1.0 & 1.6 & 1.0 & 1.0 & 1.0 & 1.0 \\
FOM + CLO + PRO & 2.0 &
\end{tabular}

Table 9. Mass accumulation of soybean shoots in $\mathrm{g} \mathrm{plants}^{-1}$, after simulating different time periods between herbicide application at preemergence and crop sowing. Maringá-PR/2013.

\begin{tabular}{|c|c|c|c|c|c|c|c|c|c|c|}
\hline \multirow{3}{*}{$\begin{array}{c}\text { Herbicides } \\
\text { FOM }\end{array}$} & \multicolumn{10}{|c|}{ Period of time (days) between application and $\mathrm{RR}^{\circledR}$ soybean sowing } \\
\hline & \multicolumn{2}{|c|}{0} & \multicolumn{2}{|c|}{70} & \multicolumn{2}{|c|}{140} & \multicolumn{2}{|c|}{210} & \multicolumn{2}{|c|}{280} \\
\hline & 0.46 & $\mathrm{Aa}$ & 0.55 & $\mathrm{Aa}$ & 0.56 & $\mathrm{Aa}$ & 0.55 & $\mathrm{Aa}$ & 0.51 & $\mathrm{Aa}$ \\
\hline PRO & 0.24 & $\mathrm{Bb}^{-}$ & 0.55 & $\mathrm{Aa}$ & 0.55 & $\mathrm{Aa}$ & 0.55 & $\mathrm{Aa}$ & 0.53 & $\mathrm{Aa}$ \\
\hline DIU & 0.05 & $\mathrm{Cc}^{-}$ & 0.21 & $\mathrm{Bc}^{-}$ & 0.48 & $\mathrm{Aa}$ & 0.55 & $\mathrm{Aa}$ & 0.55 & $\mathrm{Aa}$ \\
\hline S-MET & 0.54 & $\mathrm{Aa}$ & 0.57 & $\mathrm{Aa}$ & 0.56 & $\mathrm{Aa}$ & 0.58 & $\mathrm{Aa}$ & 0.57 & $\mathrm{Aa}$ \\
\hline CLO & 0.46 & $\mathrm{Aa}$ & 0.57 & $\mathrm{Aa}$ & 0.58 & $\mathrm{Aa}$ & 0.58 & $\mathrm{Aa}$ & 0.58 & $\mathrm{Aa}$ \\
\hline $\mathrm{FOM}+\mathrm{PRO}$ & 0.44 & $\mathrm{Aa}$ & 0.59 & $\mathrm{Aa}$ & 0.54 & $\mathrm{Aa}$ & 0.56 & $\mathrm{Aa}$ & 0.54 & $\mathrm{Aa}$ \\
\hline FOM + DIU & 0.07 & $\mathrm{Cc}^{-}$ & 0.39 & $\mathrm{Bb}$ & 0.55 & $\mathrm{Aa}$ & 0.56 & $\mathrm{Aa}$ & 0.58 & $\mathrm{Aa}$ \\
\hline $\mathrm{FOM}+\mathrm{S}-\mathrm{MET}$ & 0.45 & $\mathrm{Aa}$ & 0.59 & $\mathrm{Aa}$ & 0.55 & $\mathrm{Aa}$ & 0.57 & $\mathrm{Aa}$ & 0.52 & $\mathrm{Aa}$ \\
\hline $\mathrm{FOM}+\mathrm{CLO}$ & 0.51 & $\mathrm{Aa}$ & 0.57 & $\mathrm{Aa}$ & 0.55 & $\mathrm{Aa}$ & 0.56 & $\mathrm{Aa}$ & 0.62 & $\mathrm{Aa}$ \\
\hline $\mathrm{FOM}+\mathrm{CLO}+\mathrm{DIU}$ & 0.03 & $\mathrm{Cc}^{-}$ & 0.25 & $\mathrm{Bc}^{-}$ & 0.50 & $\mathrm{Aa}$ & 0.55 & $\mathrm{Aa}$ & 0.57 & $\mathrm{Aa}$ \\
\hline $\mathrm{FOM}+\mathrm{CLO}+\mathrm{PRO}$ & 0.20 & $\mathrm{Bb}^{-}$ & 0.55 & $\mathrm{Aa}$ & 0.55 & $\mathrm{Aa}$ & 0.57 & $\mathrm{Aa}$ & 0.60 & $\mathrm{Aa}$ \\
\hline Untreated control & \multicolumn{10}{|c|}{0.55} \\
\hline LSD additional control & \multicolumn{10}{|c|}{0.24} \\
\hline $\mathrm{CV}(\%)$ & \multicolumn{10}{|c|}{24.19} \\
\hline
\end{tabular}

Differ from untreated control by the Dunnet test at $5 \%$ probability: - significantly lower and ${ }^{+}$significantly higher; Means followed by the same letter, uppercase in the line and lowercase in the column, do not differ by the Scott-Knott test at 5\% probability.

For planting after the second shortest period after herbicide application (70 DAA), only treatments with diuron caused lower accumulation of dry matter per plant. In contrast, the mixture of fomesafen + diuron did not affect this variable when compared to the additional untreated control. From 140 days after application onwards, no difference was observed for this variable.

Applications of isolated diuron and the mixtures fomesafen + diuron, fomesafen + clomazone + diuron can affect dry matter when sowing is carried out prior to 215, 142, and 194 DAA respectively (Figure 3 ).

In the case of a frustrating cotton season, in which soybeans would have to be sown within a period 70 days after the application of any of the treatments evaluated in this study, only treatments with fomesafen, S-metolachlor, and clomazone alone or the combinations of S-metolachlor + clomazone + fomesafen would not stunt crop development (Table
10). Clomazone is registered for preemergence use in soybeans (RODRIGUES; ALMEIDA, 2011) as well as S-metolachlor, as previously mentioned.

When prometryne is applied alone or in combination with fomesafen or fomesafen + clomazone, a period of at least 70 DAA is indicated before implementing the crop. Inoue et al. (2011) evaluated ametryne persistence (1600 and $2400 \mathrm{~g} \mathrm{ha}^{-1}$ ) and found that regardless of rate and soil type (Oxisol and Entisol), it controlled up to $80 \%$ of Cucumis sativus until 40 DAA. Ametryne belongs to the same chemical group of prometryne ( $\mathrm{s}$ -triazines), and both have similar chemical properties, such as $\mathrm{pKa}$ and half-life in soil (RODRIGUES; ALMEIDA, 2011). Nonetheless, it is relevant to mention that cucumber ( $C$. sativus) is used as a bioindicator of herbicide in soil due to its high sensitivity to some herbicides as ametryne (SILVA et al., 2007; NUNES; VIDAL, 2009). 


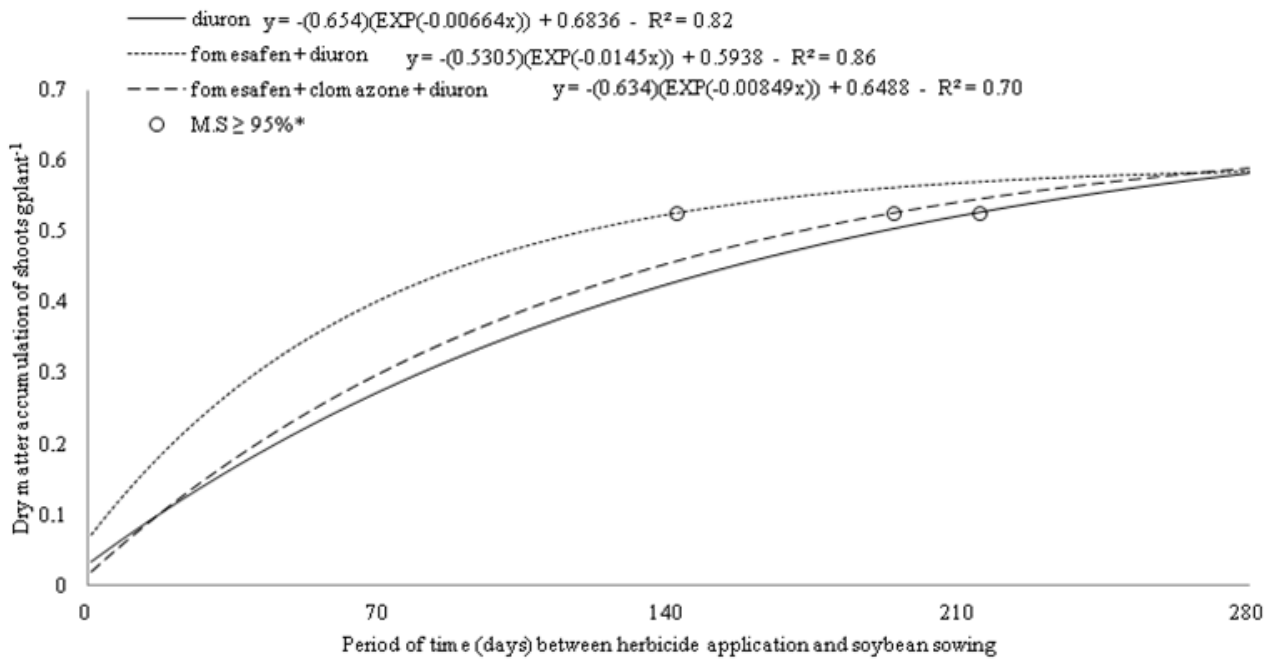

Days after application $($ diuron $=215$; fomesafen + diuron $=142$; fomesafen + clomazone + diuron $=$ 194 ) in which the dry matter accumulation of soybean shoots was $\geq 95 \%$ compared to the untreated control.

Figure 3. Dry matter accumulation of soybean shoots after increasing time periods between the application of preemergence herbicides and sowing. Maringá-PR/2013.

Table 10. Minimum period of time considered safe (days) in order to avoid significant phytointoxication on beans, corn, and soybeans as a result of herbicides applied at cotton preemergence. Maringá - PR/2013.

\begin{tabular}{cccc}
\hline Herbicide - Rate $\left(\mathrm{g} \mathrm{ha}^{-1}\right)$ & \multicolumn{2}{c}{ Period of time $^{*}$} \\
\cline { 2 - 4 } FOM (625) & Bean & Corn & Soybean \\
PRO (1250) & 0 & 70 & 0 \\
DIU (1250) & 0 & 70 & 70 \\
S-MET (768) & 207 & 70 & 0 \\
CLO (1000) & 0 & 0 & 0 \\
FOM + PRO (625+1250) & 0 & 70 & 70 \\
FOM + DIU (625+1250) & 0 & 186 & 0 \\
FOM + S-MET (625+768) & 0 & 70 & 0 \\
FOM + CLO (625+1000) & $>280$ & 230 & 194 \\
FOM + CLO + DIU (450+1000+1250) & 70 & 70 & 70 \\
FOM + CLO + PRO (450+1000+1250)
\end{tabular}

"Minimum period of time considered safe (days) to avoid significant phytotoxicity.

\section{CONCLUSION}

All three crops evaluated can be sown immediately after the application of S-metolachlor. For beans and soybeans, there are no restrictions on the safe time period between sowing and the application of mixtures of S-metolachlor and fomesafen.

Fomesafen + prometryne did not present any residual activity capable of causing injuries to beans. For soybeans, sowing can be performed immediately after the use of clomazone or clomazone + fomesafen.

Treatments with diuron showed greater persistence, thus causing greater carryover for all three crops. The other treatments hindered crop development when sowings were carried out within 70 days after application.

\section{REFERENCES}

ANDRADE, A. S. et al. Potencial de lixiviação de herbicidas em solos agrícolas na região do Alto Paranaíba (MG). Pesticidas: Revista de Ecotoxicologia e Meio Ambiente, Curitiba, v. 21, n. 1, p. 95-102, 2011.

ARTUZI, J. P.; CONTIERO, R. L. Herbicidas aplicados na soja e produtividade do milho em sucessão. Pesquisa Agropecuária Brasileira, Brasilia, v. 41, n. 2, p. 1119-1123, 2006.

BRIGHENTI, A. M. et al. Persistência e fitotoxicidade do herbicida atrazine aplicado na cultura do milho sobre a cultura do girassol em sucessão. Planta Daninha, Viçosa, v. 20, n. 2, p. 291-297, 2002.

BELTRÃO, N. E. et al. Fitotoxicidade, controle de plantas daninhas e sintomatologia de injúrias dos herbicidas diuron, pendimethalin e oxidiazon na

Rev. Caatinga, Mossoró, v. 29, n. 1, p. 143 - 152, jan. - mar., 2016 
cultura do algodão: dosagens agronômicas e duplas. Revista Brasileira de Oleaginosas e Fibrosas, Campina Grande, v. 5, n. 1, p. 241-254, 2001.

COBBUCI, T. et al. Effect of imazomax, fomesafen, and acifluoren soil residue on rotational crops. Weed Science, Champaign, v. 46, n. 2, p. 258-263, 1998.

CONAB. Séries históricas. Disponível em: <http:// www.conab.gov.br>. Acesso em: 06/04/2015.

DAN, H. A. et al. Resíduos de herbicidas utilizados na cultura da soja sobre o milho cultivado em sucessão. Revista Caatinga, Mossoró, v. 25, n. 1, p. 86-91, 2012.

FERNANDES, C. P. C. et al. Tolerância do feijoeiro a herbicidas aplicados na cultura da cana-de-açúcar. Revista Brasileira de Herbicidas, Londrina, v. 10, n. 2, p. 121-133, 2011.

FERRI, M. V. W.; VIDAL, R. A. Persistência do herbicida acetochlor em função de sistemas de preparo e cobertura com palha. Ciência Rural, Santa Maria, v. 33, n. 3, p. 399-404, 2003.

FILHO, J. S. et al. Fitomassa e cobertura do solo de culturas de sucessão ao milho na Região do Cerrado. Pesquisa Agropecuária Brasileira, Brasília, v. 39, n. 4, p. 327-334, 2004

INOUE, M. H. et al. Efeito residual de herbicidas aplicados em pré-emergência em diferentes solos. Planta Daninha, Viçosa, v. 29, n. 2, p. 429-435, 2011.

INOUE, M. H. et al. Seletividade de herbicidas aplicados em pré-emergência na cultura do algodão. Revista Ciência Agronômica, Fortaleza, v. 44, n. 1, p. 123-132, 2013.

LAMEGO, F. P. et al. Seletividade dos herbicidas Smetolachlor e alachlor para o feijão-carioca. Planta Daninha, Viçosa, v. 29, n. 4, p. 877-883, 2011.

LIEBL, R. Cell growth inhibitors (cloroacetamides, cabomothioates, napropamide, bensulide). In: LIEBL, R (Ed.). Herbicide action. West Lafayette: Purdue University, 1995. v. 1, p. 200-224.

LIU, L. C. et al. Adsorption of ametryne and diuron by soils. Weed Science, Champaign, v. 18, n. 4, p. 470-474, 1970.

NUNES, A. L.; VIDAL, R. A. Seleção de plantas quantificadoras de herbicidas residuais. Pesticidas: Revista de Ecotoxicologia e Meio Ambiente, Curitiba, v. 19, n. 1, p. 19-28, 2009.

NUNES, R. de S. et al. Sistemas de manejo e os estoques de carbono e nitrogênio em latossolo de cerrado com a sucessão soja-milho. Revista Brasileira de Ciência do solo, Viçosa, v. 35, n. 4, p. 1407-1419, 2011.

OLIVEIRA, M. F.; PRATES, H. T.; SANS, L. M. A. Sorção e hidrólise do herbicida flazasulfuron. Planta Daninha, Viçosa, v. 23, n. 1, p. 101-113, 2005.

OLIVEIRA NETO, A. M. et al. Selectivity of fomesafen to cotton. Planta Daninha, Viçosa, v. 33, n. 4, p. 759-770, 2015.

RODRIGUES, B. N.; ALMEIDA, F. S. Guia de herbicidas. 6. ed. Londrina, PR: IAPAR, 2011. 56, 197, 317, 582 p.

SANTOS, G. et al. Carryover proporcionado pelos herbicidas s-metolachlor e trifluralin nas culturas de feijão, milho e soja. Planta Daninha, Viçosa, v. 30, n. 4, p. 827-834, 2012.

SANTOS, R. L. B.; SPEHAR, C. R.; VIVALDI, L. Quinoa (Chenopodium quinoa) reaction to herbicide residue in a Brazilian Savannah soil. Pesquisa Agropecuaria. Brasileira, Brasília, v. 38, n. 6, p. 771-776, 2003.

SILVA, C. M. et al. Efeito residual da aplicação de fluazifop-p-butil + fomesafen em solos com plantasteste. Ciência Rural, Santa Maria, v. 37, n. 5, p. 1450-1452, 2007.

TAKANO, H. K. et al. Potencial de utilização do dietholate como protetor de clomazone em feijoeiro comum. Revista Brasileira de Herbicidas, Londrina, v. 11, n. 3, p. 305-315, 2013.

TORRES, J. L. R. et al. Produtividade de feijão sobre lâminas de irrigação e coberturas de solo. Bioscience Journal, Uberlândia, v. 29, n. 4, p. 833 841,2013

WEBER, J. B. Ionization and sorption of fomesafen and atrazine by soils and soil constituents. Pesticide Science, Malden, v. 38, n. 1, p. 39-38, 1993.

WEBSTER, T. M. et al. Culpepper cotton planting date affects the critical period of benghal dayflower (Commelina benghalensis) control. Weed Science, Champaign, v. 57, n. 2, p. 81-86, 2009. 